\title{
PENYULUHAN HUKUM HAK DAN KEWAJIBAN WAJIB PAJAK BAGI PESERTA DIDIK SEKOLAH MENENGAH ATAS NEGERI (SMAN) 10 JAKARTA PUSAT
}

\author{
Evie Rachmawati Nur Ariyanti $^{1 *}$, Nurul Fajri Chikmawati ${ }^{1}$, Liza Evita ${ }^{1}$ \\ Fakultas Hukum Universitas YARSI, Jakarta \\ * Penulis Korespondensi: evie.rachmawati@yarsi.ac.id
}

\begin{abstract}
Abstrak
Pasal 23 A Undang-Undang Dasar Negara Republik Indonesia Tahun 1945 menyatakan bahwa pajak dan pungutan lain yang bersifat memaksa untuk keperluan negara diatur dengan undang-undang. Kewenangan pemerintah untuk memungut pajak merupakan lingkup pengertian dari hukum pajak. Pemberian penyuluhan hukum pajak kepada peserta didik di tingkat Sekolah Menengah Atas (SMA) perlu dilakukan karena mereka merupakan calon wajib pajak. Kegiatan penyuluhan hukum tentang hak dan kewajiban wajib pajak ditujukan kepada peserta didik kelas XII jurusan IPS karena pengetahuan tentang pajak telah sedikit mereka ketahui dari mata pelajaran ekonomi. Kewajiban warga negara bersinergi dengan hak yang telah diterima oleh warga negara. Artinya, ketika hak itu menjadi bagian yang dituntut warga negara, maka muncul kewajiban warga negara sebagai penyeimbangnya. Pengabdian kepada masyarakat ini memberikan manfaat bagi kelompok mitra di SMAN 10 Jakarta Pusat sehingga para peserta didik memperoleh pengetahuan tentang hak dan kewajiban wajib pajak.
\end{abstract}

Kata Kunci: Hak, Kewajiban, Pajak

\begin{abstract}
Article 23A of the Constitution of the Republic of Indonesia 1945 states that taxes and other coercivelevies for the state purposes is regulated by law. Government authority collecting taxes is the definitionscope of tax law. The education of tax law for SMA students is necessary because they are the candidates of taxpayer. This activity was addressed for IPS major XII grade students because they have known a little about taxes in the economic subjects. The obligation of citizens is followed with the rights which they have accepted. It means when citizens sue their rights, then they have some obligation for balancing.The community dedication give some benefit for partners group at SMAN 10 Jakarta with the result that the students acquire some knowledge about the rights and obligations of the taxpayer.
\end{abstract}

Keywords: Rights, Obligation, Tax

\section{PENDAHULUAN}

Pajak merupakan salah satu sumber pembiayaan yang sangat potensial karena Anggaran Pendapatan dan Belanja Negara (APBN) Republik Indonesia tidak cukup mengandalkan sumber dana dari hasil minyak bumi, gas alam, dan penghasilan non pajak lainnya. Hasil pajak yang dipungut pemerintah dari masyarakat tidak hanya digunakan untuk membiayai pengeluaran rutin tetapi ditujukan pula untuk pembangunan di segala bidang.

Penerimaan negara terdiri atas 3 (tiga) sumber, yakni penerimaan perpajakan, penerimaan negara bukan pajak, dan penerimaan hibah. Penerimaan perpajakan terdiri dari penerimaan pajak dan penerimaan dari bea dan cukai. Pajak menjadi sumber pendapatan yang besar bagi negara Indonesia saat ini. Penerimaan pajak berkontribusi sebesar 74,63\% dari seluruh penerimaan negara untuk keperluan pembiayaan pembangunan. Penerimaan pajak telah menjadi sumber utama penerimaan negara menggantikan penerimaan dari Sumber Daya Alam (SDA). Pada periode 1980-1990 penerimaan dari SDA menjadi sumber utama penerimaan negara. Sumber utama penerimaan negara dalam kurun waktu 5 (lima) tahun terakhir ini berasal dari pajak. Saat ini, SDA memang masih mendukung penerimaan negara, namun perannya semakin lama semakin menurun, serta lama kelamaan akan habis dan dapat merusak keseimbangan alam. 
Perpajakan di Indonesia menerapkan sistem yang memberikan kepercayaan kepada Wajib Pajak untuk memenuhi kewajiban perpajakannyadengan menghitung, memperhitungkan, menyetorkan dan melaporkan pajak sendiri jumlah pajak yang harus dibayar ke negara (Self Assessment System/SAS). Untuk menjamin sistem ini berjalan dengan baik, maka diperlukan pengetahuan dan kesadaran yang cukup sehingga wajib pajak dan masyarakat dapat melaksanakan kewajiban perpajakannya dengan baik.

Realisasi penerimaan pajak dalam kurun waktu 5 (lima) tahun terakhir tidak mencapai target seperti yang diharapkan. Salah satunya disebabkan oleh rendahnya tingkat kesadaran dan kepatuhan Wajib Pajak. Rendahnya kepatuhan Wajib Pajak di dalam melaksanakan kewajiban perpajakan, dapat dilihat dari kondisi penerimaan pajak yang ada. Berdasarkan data Direktorat Jenderal Pajak (2016), pada tahun 2015 realisasi penerimaan pajak hanya sebesar Rp $1.061,2$ triliun atau $82 \%$ dari target yang telah ditetapkan sebesarRp 1.294,3 triliun. Setahun sebelum nya, realisasi penerimaan pajak adalah $\mathrm{Rp} 981,9$ triliun atau 91,6\% dari target sebesar $\mathrm{Rp} 1.072,3$ triliun. Pada tahun 2013 realisasi penerimaan pajak adalah sebesar Rp 916,2 triliun atau sebesar 92,1\% dari target sebesar Rp 995,2 triliun. Begitu pula di tahun 2012, penerimaan pajak adalah sebesar Rp 835,3 triliun atau 94,4\% dari target sebesar Rp885 triliun. Pada tahun 2011 realisasi penerimaan pajak adalah Rp 742,6 triliun atau 97,2\% dari target sebesar Rp 763,6 triliun.

Menurut Winarno (2011) wujud hubungan antara warga negara dan negara pada umumnya berupa peranan (role). Peranan pasif adalah kepatuhan warga negara terhadap peraturan perundang-undangan yang berlaku. Peranan aktif merupakan aktivitas warga negara untuk terlibat atau berpartisipasi serta ambil bagian dalam kehidupan bernegara, terutama dalam mempengaruhi keputusan publik. Peranan positif merupakan aktivitas warga negara untuk meminta pelayanan dari negara untuk memenuhi kebutuhan hidup. Peranan negatif merupakan aktivitas warga negara untuk menolak campur tangan negara dalam persoalan pribadi. Hubungan antara warga negara dengan negara di Indonesia telah diatur dalam Undang-Undang Dasar Negara Republik Indonesia Tahun 1945. Baik itu hak dan kewajiban warga negara terhadap negara maupun hak dan kewajiban negara terhadap warganya.

Sebenarnya kewajiban warga negara bersinergi dengan hak yang telah diterima oleh warga negara. Artinya ketika hak itu menjadi bagian yang dituntut warga negara, maka muncul kewajiban warga negara sebagai penyeimbangnya. Sebagaimana telah kita ketahui pemerintah Indonesia dalam memberikan perlindungan dan pelayanan terhadap warga negara sebagai salah satu upaya pemenuhan hak, membuat kebijakan dan pelayanan dengan membangun infrastruktur. Sudah dipastikan dana yang dibutuhkan tidak sedikit, oleh karena itu negara membuat pos-pos sumber dana untuk melaksanakannya. Salah satunya melalui pungutan pajak yang dibebankan kepada
rakyat.Pungutan pajak tersebut menjadi kewajiban warga negara dan dalam memenuhi unsur hak dari makna pungutan pajak yang seolah memaksa, maka negara diwajibkan membuat peraturannyasupaya tetap memenuhi hak warga negara sehingga tidak terjadi kesewenangan. Landasan hukum tertinggi bagi negara untuk memungut pajak terdapat dalam Pasal 23 A Undang-Undang Dasar Negara Republik Indonesia Tahun 1945 yang menyatakan bahwa pajak dan pungutan lain yang bersifat memaksa untuk keperluan negara diatur dengan undang-undang.

Sejak dilakukan reformasi perundangundangan perpajakan tahun 1983 yang pemungutannya didasarkan pada self Assessment system, perundang-undangan perpajakan secara terus menerus mengalami perubahan. Perubahan yang terjadi dalam perundang-undangan perpajakan tersebut sejalan dengan perkembangan ekonomi, teknologi informasi, sosial, dan politik. Perubahan tersebut bertujuan untuk lebih memberikan keadilan, meningkatkan pelayanan kepada wajib pajak, meningkatkan kepastian dan penegakan hukum, serta mengantisipasi kemajuan di bidang teknologi informasi dan perubahan ketentuan material di bidang perpajakan. Selain itu, perubahan tersebut juga dimaksudkan untuk meningkatkan profesionalisme aparatur perpajakan, meningkatkan keterbukaan administrasi perpajakan, dan meningkatkan kepatuhan sukarela wajib pajak.

Menurut Ahmadi (2006), kewenangan pemerintah untuk melakukan pemungutan pajak atas kekayaan seseorang dan kemudian menyerahkan kembali kepada masyarakat melalui program kerja pemerintah dari anggaran belanja negara atau daerah merupakan lingkup pengertian dari hukum pajak. Brotodihardjo (1993) juga mengemukakan bahwa hukum pajak disebut juga hukum fiskal merupakan keseluruhan dari peraturan-peraturan yang meliputi wewenang pemerintah untuk mengambil kekayaaan seseorang dan menyerahkan kembali kepada masyarakat dengan melalui kas negara, menjadi bagian dari hukum publik yang mengatur hubunganhubungan hukum antara negara dan orang-orang atau badan-badan (hukum) yang berkewajiban membayar pajak (selanjutnya disebut wajib pajak).

Memperkenalkan hukum pajak sejak dini menjadi sedikit jawaban atas rendahnya kesadaran pajak dalam diri masyarakat Indonesia saat ini. Pajak yang pada dasarnya merupakan kewajiban yang mengikat kepada setiap warga negara dan telah dilegalkan dalam Undang-Undang Dasar Negara Tahun 1945 ternyata tak sepenuhnya dipatuhi masyarakat. Akibatnya, peran pajak yang sangat penting dalam pembangunan tidak sepenuhnya terpenuhi. Pemberian penyuluhan hukum pajak kepada calon wajib pajak khususnya peserta didik di tingkat Sekolah Menengah Atas (SMA) dirasakan perlu karena asumsinya adalah di kemudian hari mereka akan menjadi bagian dari masyarakat yang menjalankan aktivitas ekonominya atau lebih tepatnya mereka sebagai calon wajib pajak yang nantinya akan melaksanakan kewajiban perpajakan di saat mereka 
telah bekerja. Bahkan sekarang ini banyak anak-anak di usia sekolah sudah melakukan berbagai kegiatan usaha bisnis dari yang pendapatannya kecil hingga ratusan juta rupiah.

Perpajakan dalam materi kurikulum 2013 untuk tingkat Sekolah Menengah Kejuruan (SMK), dimasukan dalam kompetensi kejuruan akuntansi dengan jadwal tersendiri pada kelas XI dan XII. Sementara untuk tingkat SMA belum memasukkan materi perpajakan secara maksimal. Belum adanya jadwal khusus mempelajari perpajakan pada tingkat SMA, sudah dapat dipastikan penyampaian informasi perpajakan kepada pelajar sangat tidak maksimal. Materi Perpajakan dalam kurikulum 2013 untuk SMK sebenarnya sudah cukup untuk menyampaikan informasi perpajakan kepada pelajar jika juga diajarkan pada tingkat SMA. Berdasarkan uraian tersebut di atas, tim pengabdian Fakultas Hukum Universitas YARSI hendak melakukan kegiatan penyuluhan hukum hak dan kewajiban pajak bagi peserta didik di SMA 10 Jakarta Pusat.

Sekolah Menengah Atas Negeri (SMAN) 10 Jakarta berdiri pada tanggal 16 Agustus 1962, berlokasi di Sekolah Menengah Pertama Negeri (SMPN) 17 Jakarta dengan kepala sekolah pertama yaitu Bapak T.B. Zakaria. Sebelumnya, SMAN 10 merupakan filial dari SMAN 2 Jakarta Barat. Pada tahun 1965, SMA Negeri 10 Jakarta membuka kelas jauh yang berlokasi di Pademangan Timur yang kemudian berkembang menjadi SMAN 15 Jakarta. Pada tahun 1974 kembali membuka kelas jauh di Pademangan IV Jakarta Utara yang saat ini dikenal dengan nama SMAN 40 Jakarta. SMAN 10 berlokasi di jalan Mangga Besar XIII Sawah Besar Jakarta Pusat. Kegiatan penyuluhan hukum tentang hak dan kewajiban wajib pajak ini ditujukan kepada para siswa dan siswi yang duduk di kelas XII jurusan IPS karena mereka sebentar lagi yang akan menyelesaikan sekolah dan melanjutkan studi ke jenjang berikutnya atau mempunyai keinginan untuk bekerja setelah lulus SMA. Selain itu pengetahuan tentang pajak telah sedikit mereka ketahui dari mata pelajaran ekonomi. Walaupun demikian, sedikit dari mereka yang tahu bahwa pajak juga dapat dilihat dari aspek hukumnya sehingga pemahaman mereka tentang hukum pajak belum dimengerti secara keseluruhan.

Dari analisis situasi di atas, kondisi yang ada saat ini adalah:

1. Pada umumnya peserta didik di SMAN 10 belum memahami secara benar tentang hukum pajak.

2. Para peserta didik belum pernah mendapatkan penyuluhan tentang hak dan kewajiban wajib pajak.

3. Para peserta didik kesulitan memperoleh informasi tentang hukum pajak yang dapat dijadikan referensi dalam proses pembelajaran.

Berdasarkan uraian tersebut di atas, maka masalah yang dapat dirumuskan adalah bagaimanakah pelaksanaan penyuluhan hukum hak dan kewajiban wajib pajak di Sekolah Menengah Atas Negeri (SMAN) 10 Jakarta Pusat untuk meningkatkan pengetahuan dan pemahaman hukum pajak bagi peserta didik khususnya kelas XII jurusan IPS?

\section{METODE PELAKSANAAN}

Kegiatan pengabdian kepada masyarakat ini dilakukan dengan metode participatory action dalam bentuk ceramah dan diskusi. Pelaksanaan metode ini digunakan waktu sebanyak $40 \%$ untuk penyampaian materi atau ceramah sedangkan sisanya $60 \%$ digunakan untuk diskusi dan tanya jawab. Pada awalnya akan dilakukan tes awal (pre test) untuk mengungkap seberapa jauh pengetahuan peserta didik kelas XII di Sekolah SMAN 10 Jakarta Pusat tentang perpajakan. Kemudian dilakukan pembekalan materi dan diakhiri dengan tanya jawab atau diskusi. Setelah dilakukan pembekalan materi dan diskusi selesai dilakukan, akan dievaluasi dengan tes akhir (post test) untuk mengetahui apakah materi benar-benar terserap dan dipahami oleh para peserta didik.

\section{HASIL DAN PEMBAHASAN Hasil Kegiatan}

Kegiatan penyuluhan dilakukan terhadap peserta didik kelas XII jurusan IPS dan IPA. Sebelum materi diberikan, tim pelaksana penyuluhan membagikan lembaran tes awal (pre test) kepada para peserta didik untuk dikerjakan dan dikumpulkan. Untuk mengetahui kelancaran kegiatan selama penyuluhan, maka dapat dilakukan dengan menggambarkan bagaimana berlangsungnya kegiatan.

Setelah pembukaan, kegiatan diawali dengan tes awal (pre test). Kemudian dilanjutkan dengan penyampaian materi. Materi penyuluhan diawali dengan pemberian pengetahuan tentang pajak dan hukum pajak yang dilanjutkan dengan asas-asas pemungutan pajak. Materi selanjutnya berupa subjek dan wajib pajak serta hak dan kewajiban wajib pajak.

Berdasarkan pemantauan dan pengamatan, selama berlangsungnya kegiatan ini perhatian para peserta didik terhadap materi-materi yang disampaikan cukup tinggi. Hal ini dapat dilihat dari tingginya perhatian para peserta didik dan banyaknya para peserta didik yang mengajukan pertanyaan. Pertanyaan yang diajukan tidak hanya menyangkut teknis perpajakan, tetapi juga berkembang ke masalah hukum lain yang sedang mengemuka yang masih berkaitan dengan perpajakan. Setelah penyampaian materi dan tanya jawab, kegiatan ditutup dengan tes akhir (post test).

Evaluasi awal dan evaluasi akhir dilakukan untuk mengetahui sejauh mana kegiatan ini dapat diserap dan bermanfaat bagi para peserta didik. Siswa dan siswi kelas XII jurusan IPS sudah mendapatkan pengetahuan pajak dari mata pelajaran ekonomi dan pendidikan kewarganegaraan, sedangkan siswa dan siswi kelas XII jurusan IPA sedikit mendapat pengetahuan pajak dari mata pelajaran pendidikan kewarganegaraan. Selain itu, ada beberapa peserta 
didik yang sudah mendapat informasi tentang pajak dari media massa dan internet.

\section{Pembahasan}

Penyuluhan hukum menurut Soekanto (1986) merupakan jenis bantuan hukum tertentu, yakni bantuan hukum preventif. Penyuluhan hukum tersebut merupakan suatu kegiatan, di mana secara sengaja dan terencana memberikan bantuan (hukum) kepada pihak-pihak tertentu melalui komunikasi supaya pihak-pihak tersebut mampu untuk mengambil suatu keputusan. Tujuan utama dari penyuluhan hukum adalah agar warga masyarakat memahami hukum yang berlaku sehingga hukum tersebut melembaga dan bahkan menjiwai warga masyarakat yang bersangkutan.

Menurut Soemitro (1992), pajak adalah peralihan kekayaan dari sektor swasta ke sektor publik berdasarkan undangundang yang dapat dipaksakan dengan tidak mendapatkan imbalan (tegenprestatie) yang secara langsung dapat ditunjukkan yang digunakan untuk membiayai pengeluaran umum dan yang digunakan sebagai alat pendorong, penghambat atau pencegah untuk mencapai tujuan yang ada di luar bidang keuangan negara. Definisi pajak baru diatur dalam undangundang pada tahun 2007. Berdasarkan Pasal 1 Angka 1 Undang-Undang Nomor 28 Tahun 2007 Tentang Perubahan Ketiga Atas Undang-Undang Nomor 6 Tahun 1983 Tentang Ketentuan Umum dan Tata Cara Perpajakan (selanjutnya disebut UU KUP), pajak didefinisikan sebagai berikut:

"Pajak adalah kontribusi wajib kepada kas negara yang terutang oleh orang pribadi atau badan yang bersifat memaksa berdasarkan Undang-Undang, dengan tidak mendapatkan imbalan secara langsung dan digunakan untuk keperluan negara bagi sebesar besarnya kemakmuran rakyat".

Berdasarkan definisi tersebut di atas, maka dapat disimpulkan bahwa ada 5 (lima) unsur yang melekat dalam pengertian pajak yaitu:

1. pembayaran pajak harus berdasarkan UU;

2. sifatnya dapat dipaksakan;

3. tidak ada kontra-prestasi (imbalan) yang langsung dapat dirasakan oleh pembayar pajak;

4. pemungutan pajak dilakukan oleh negara, baik oleh pemerintah pusat maupun daerah (tidak boleh dipungut swasta); dan

5. pajak digunakan untuk membiayai berbagai pengeluaran pemerintah (rutin dan pembangunan) bagi kepentingan masyarakat umum.

Pemerintah dalam memungut pajak, terdapat asas-asas atau prinsip-prinsip yang harus diperhatikan dalam sistem pemugutan pajak. Beberapa asas yang penting untuk diperhatikan dalam mendesain sistem pemungutan pajak menurut Rosdiana (2012) adalah sebagai berikut:

1. asas keadilan (equity/equality), yaitu pengenaan pajak kepada orang-orang pribadi sebanding dengan kemampuannya untuk membayar pajak tersebut dan juga sesuai dengan manfaat yang diterimanya dari negara;

2. asas kepastian (certainty), yaitu pemungutan pajak harus mencakup kepastian mengenai subjek pajak, objek pajak, dasar pengenaan pajak, tarif pajak, prosedur pemenuhan kewajiban serta pelaksanaan hak-hak perpajakannya;

3. asas menyenangkan (convenience), yaitu pembayaran pajak hendaklah dimungkinkan pada saat yang menyenangkan atau memudahkan wajib pajak;

4. asas ekonomis (efficiency), yaitu biaya pemungutan pajak tidak boleh lebih besar dari hasil pajak yang akan diterima.

Menurut Saidi (2011), subjek pajak dengan wajib pajak memiliki perbedaan secara hukum. Subjek pajak bukan subjek hukum, melainkan hanya wajib pajak sebagai subjek hukum. Subjek pajak tidak memenuhi syarat-syarat, baik syarat-syarat subjektif atau syarat-syarat objektif untuk dikenakan pajak sehingga bukan subjek hukum. Sebaliknya, wajib pajak pada awalnya berasal dari subjek pajak yang dikenakan pajak karena memenuhi syarat-syarat subjektif dan objektif yang telah ditentukan. Dengan demikian, ada keterkaitan antara subjek pajak dengan wajib pajak, walaupun keduanya dapat dibedakan secara hukum karena keberadaan wajib pajak bermula dari subjek pajak. Berdasarkan Pasal 1 Angka 2 UU KUP yang disebut wajib pajak adalah sebagai berikut: "Wajib pajak adalah orang pribadi atau badan, meliputi pembayar pajak, pemotong pajak, dan pemungut pajak yang mempunyai hak dan kewajiban perpajakan sesuai dengan ketentuan peraturan perundang-undangan perpajakan”.

Wajib pajak dalam UU PPh, terdiri dari wajib pajak dalam negeri dan wajib pajak luar negeri. Wajib pajak dalam negeri adalah subjek pajak dalam negeri yang memenuhi syarat-syarat objektif, artinya memenuhi syarat-syarat seperti yang ditentukan dalam UU PPh. Wajib pajak dalam negeri adalah subjek pajak yang bertempat tinggal atau menetap di Indonesia. Wajib pajak dalam negeri dikenakan pajak di tempat ia tinggal atau berkedudukan. Kemudian, wajib pajak dalam negeri dikenakan pajak atas semua penghasilan yang diterima atau diperolehnya, baik yang diterima di dalam negeri maupun di luar negeri. Orang asing yang berada di Indonesia untuk jangka waktu secara berturut-turut yang lebih dari seratus delapan puluh tiga hari dianggap sebagai wajib pajak dalam negeri dan wajib memenuhi kewajiban dan haknya selaku wajib pajak dalam negeri. Pejabat diplomatik dan pegawai kedutaan Republik Indonesia yang karena jabatannya berada di luar Indonesia, dengan ketentuan bahwa mereka bukan staf lokal, masih merupakan wajib pajak dalam negeri asas eksteritorialitas, yakni mereka dianggap bertempat tinggal di wilayah Republik Indonesia dan wajib pula membayar pajak penghasilan ketika penghasilannya melebihi penghasilan tidak kena pajak. 
UU KUP mengakomodir mengenai hak dan kewajiban wajib pajak dalam rangka untuk lebih memberikan keadilan di bidang perpajakan. Beberapa kewajiban wajib pajak adalah sebagai berikut:

1. mendaftarkan diri pada kantor Direktorat Jenderal Pajak yang wilayah kerjanya meliputi tempat tinggal atau tempat kedudukan wajib pajak dan kepadanya diberikan Nomor Pokok Wajib Pajak (NPWP);

2. melaporkan usahanya pada kantor Direktorat Jenderal Pajak yang wilayah kerjanya meliputi tempat tinggal atau tempat kedudukan pengusaha, dan kegiatan usaha dilakukan untuk dikukuhkan sebagai pengusaha kena pajak, dan kepadanya diberikan Nomor Pengukuhan Pengusaha Kena Pajak (NPPKP);

3. menyelenggarakan dan/ atau memperlihatkan pembukuan atau pencatatan-pencatatan maupun data-data yang diperlukan oleh pemeriksa pajak;

4. membayar atau menyetor pajak di tempat yang telah ditentukan oleh UU.

Berdampingan dengan kewajiban adalah hak. Wajib pajak mempunyai hak yang wajib diindahkan oleh pihak administrasi pajak. Hak-hak wajib pajak dapat digunakan atau dimanfaatkan pada saat tertentu. Jika hak-haknya dilanggar oleh pihak administrasi pajak, maka wajib pajak dapat mengajukan masalahnya ke hadapan pejabat atasan orang yang melanggar haknya, atau bila perlu mengajukannya ke hadapan lembaga peradilan pajak. Beberapa hak wajib pajak adalah sebagai berikut:

1. mengajukan keberatan, banding, dan peninjauan kembali;

2. memperoleh kembali kelebihan pembayaran pajak;

3. mengajukan permohonan untuk mengangsur atau menunda pembayaran pajak.

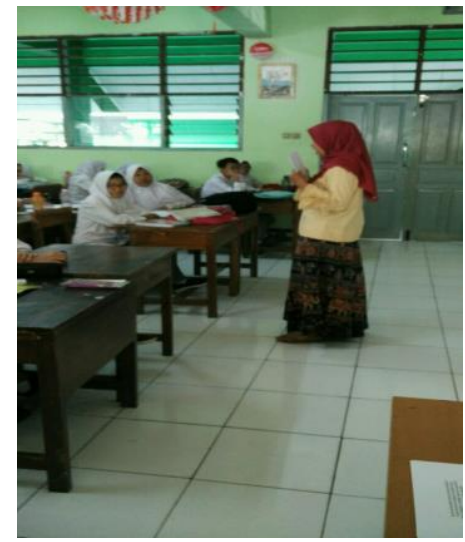

Gambar 1. Pembukaan Penyuluhan

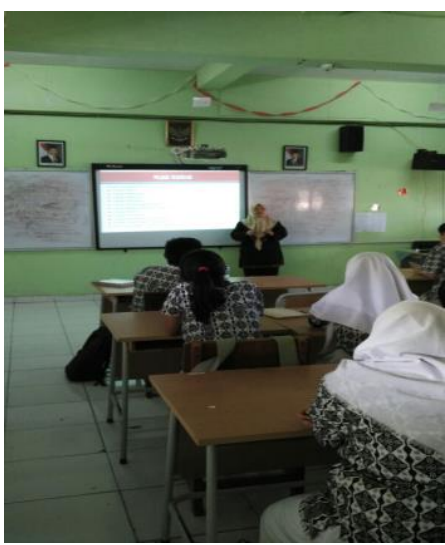

Gambar 2. Penyampaian Materi

Peserta didik kelas XII jurusan IPS sebanyak 88 orang. Setelah dilakukan pengolahan data, didapatkan hasil bahwa seluruh peserta didik kelas XII Jurusan IPS dapat menjawab dengan benar untuk pertanyaan yang pertama baik pada saat tes awal dan tes akhir. Dengan demikian, seluruh peserta sudah memahami unsur pajak. Pertanyaan kedua berkaitan dengan asas-asas pemungutan pajak. Hasilnya hanya 18 peserta yang menjawab dengan benar pada saat tes awal. Setelah diberikan materi, seluruh peserta dapat menjawab dengan benar sehingga terjadi peningkatan sebanyak 70 orang yang sudah mengetahui dan memahami asas-asas pemungutan pajak.

Terjadi peningkatan nilai rata-rata sebesar $79,55 \%$ dari sebelumnya $20,45 \%$. Pertanyaan ketiga tentang wajib pajak. Hasilnya hanya 16 peserta yang menjawab dengan benar. Setelah diberikan materi, seluruh peserta dapat menjawab dengan benar sehingga terjadi peningkatan sebanyak 72 peserta yang mengetahui dan memahami wajib pajak. Terjadi peningkatan nilai rata-rata sebesar $81,82 \%$ dari sebelumnya $18,18 \%$.

Pertanyaan yang keempat tentang hak wajib pajak. Tidak ada peserta didik yang menjawab dengan benar pada saat tes awal. Setelah diberikan materi, hanya 1 orang yang menjawab salah dan 87 orang yang sudah mengetahui dan memahami hak-hak wajib pajak. Dengan demikian, terjadi peningkatan nilai rata-rata sebesar $98,86 \%$. Pertanyaan terakhir tentang kewajiban wajib pajak. Tidak ada peserta didik yang menjawab dengan benar pada saat tes awal. Setelah diberikan materi, hanya 2 orang yang menjawab salah dan sebanyak 85 peserta yang sudah mengetahui dan memahami kewajiban wajib pajak. Dengan demikian, terjadi peningkatan nilai rata-rata sebesar $96,59 \%$. Untuk lebih jelasnya, dapat diperhatikan tabel dan gambar grafik di bawah ini berturut-turut. 
Tabel 1. Hasil Tes Awal (Pre Test) dan Tes Akhir (Post Test)

Peserta Didik Kelas XII Jurusan IPS

\begin{tabular}{|c|c|c|c|c|c|c|c|}
\hline No & Soal & $\begin{array}{c}\text { Tes } \\
\text { A } \\
\text { w } \\
\text { a } \\
1\end{array}$ & $\begin{array}{c}\text { Tes } \\
\text { A } \\
\text { k } \\
\mathrm{h} \\
\mathrm{i} \\
\mathrm{r}\end{array}$ & $\begin{array}{c}\text { Peningka } \\
\text { tan } \\
\text { Jumlah } \\
\text { Peserta } \\
\text { yang } \\
\text { Paham }\end{array}$ & $\begin{array}{c}\text { Nilai } \\
\text { Rata- } \\
\text { Rata } \\
\text { Tes } \\
\text { Aw al }\end{array}$ & $\begin{array}{c}\text { Nilai } \\
\text { Rata- } \\
\text { Rata } \\
\text { Tes } \\
\text { Akhir }\end{array}$ & $\begin{array}{c}\text { Peningka } \\
\text { tan } \\
\text { Nilai } \\
\text { Rata- } \\
\text { Rata } \\
\text { Kelas }\end{array}$ \\
\hline 1. & $\begin{array}{l}\text { Unsur } \\
\text { Pajak }\end{array}$ & 88 & 88 & 0 & 100 & 100 & 0 \\
\hline 2. & $\begin{array}{l}\text { Asas } \\
\text { Pemu } \\
\text { nguta } \\
\text { n } \\
\text { Pajak }\end{array}$ & 18 & 88 & 70 & 20,45 & 100 & 79,55 \\
\hline 3. & $\begin{array}{l}\text { Wajib } \\
\text { Pajak }\end{array}$ & 16 & 88 & 72 & 18,18 & 100 & 81,82 \\
\hline 4. & $\begin{array}{l}\text { Hak } \\
\text { Wajib } \\
\text { Pajak }\end{array}$ & 0 & 87 & 87 & 0 & 98,86 & 98,86 \\
\hline 5. & $\begin{array}{l}\text { Kewa } \\
\text { jiban } \\
\text { Wajib } \\
\text { Pajak }\end{array}$ & 0 & 85 & 85 & 0 & 96,59 & 96,59 \\
\hline
\end{tabular}

Hasil analisis tersebut di atas dapat diilustrasikan dengan grafik di bawah ini:

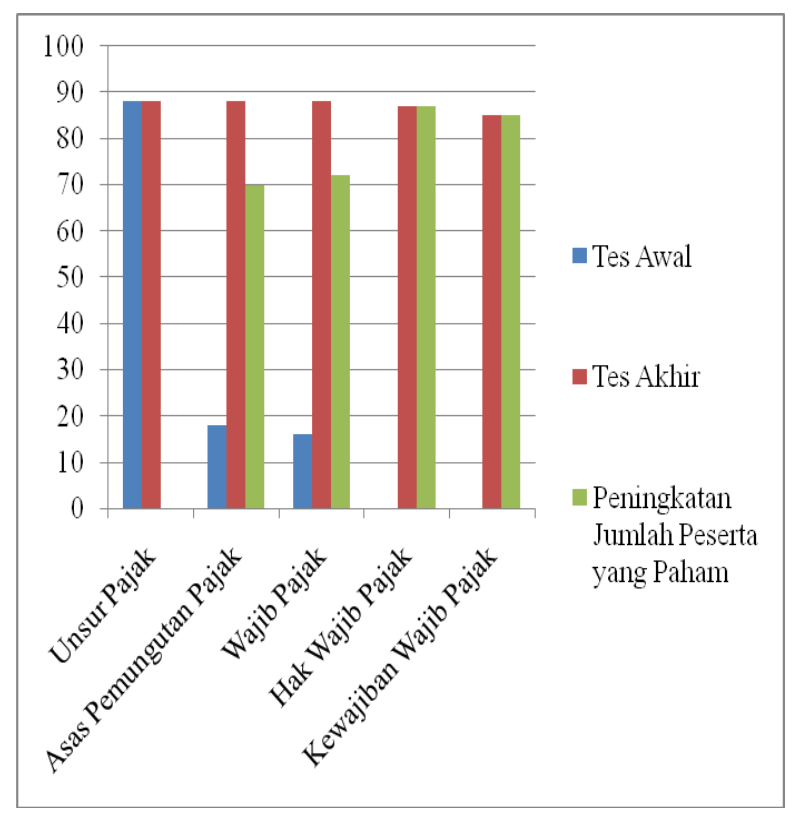

Gambar 3. Peningkatan Pemahaman Peserta Didik Kelas XII Jurusan IPS Sebelum dan Sesudah Penyuluhan Hukum

Peserta didik kelas XII jurusan IPA yang mengikuti kegiatan ini sebanyak 69 orang. Untuk pertanyaan yang pertama, seluruh peserta menjawab dengan benar pada saat tes awal dan tes akhir. Dengan demikian, seluruh peserta sudah memahami unsur pajak. Pada soal yang kedua, hanya 15 peserta didik yang menjawab dengan tepat. Setelah diberikan materi, seluruh peserta dapat menjawab dengan benar sehingga terjadi peningkatan sebanyak 54 orang yang mengetahui dan memahami asas-asas pemungutan pajak.

Terjadi peningkatan nilai rata-rata sebesar $78,26 \%$ dari sebelumnya $21,74 \%$. Hanya 10 peserta didik yang menjawab dengan tepat dari pertanyaan yang ketiga. Setelah diberikan materi, seluruh peserta dapat menjawab dengan benar sehingga terjadi peningkatan sebanyak 59 peserta yang mengetahui dan memahami tentang wajib pajak. Dengan demikian, terjadi peningkatan nilai rata-rata sebesar $78,26 \%$ dari sebelumnya $21,74 \%$. Untuk pertanyaan yang keempat, tidak ada yang menjawab dengan benar pada saat tes awal. Setelah diberikan materi, hampir seluruh peserta didik yang dapat menjawab dengan benar sehingga terjadi peningkatan sebanyak 67 peserta yang sudah mengetahui dan memahami hak-hak wajib pajak.

Dengan demikian terjadi peningkatan nilai rata-rata sebesar 97,10\%. Untuk pertanyaan yang terakhir, tidak ada peserta didik yang menjawab dengan benar pada saat tes awal. Setelah diberikan materi, hampir seluruh peserta didik yang dapat menjawab dengan benar sehingga terjadi peningkatan sebanyak 65 orang yang sudah mengetahui dan memahami kewajiban wajib pajak. Dengan demikian terjadi peningkatan nilai rata-rata sebesar 94,20\%. Untuk lebih jelasnya, dapat diperhatikan tabel dan gambar grafik di bawah ini secara berurutan.

Tabel 2. Hasil Tes Awal (Pre Test) dan Tes Akhir (Post Test)

Peserta Didik Kelas XII Jurusan IPA

\begin{tabular}{|c|c|c|c|c|c|c|c|}
\hline No & Soal & $\begin{array}{c}\text { Tes } \\
\text { A } \\
w \\
\text { a } \\
1\end{array}$ & $\begin{array}{c}\text { Tes } \\
\text { A } \\
\text { k } \\
\mathrm{h} \\
\mathrm{i} \\
\mathrm{r}\end{array}$ & $\begin{array}{c}\text { Peningka } \\
\text { tan } \\
\text { Jum lah } \\
\text { Peserta } \\
\text { yang } \\
\text { Paham }\end{array}$ & $\begin{array}{c}\text { Nilai } \\
\text { Rata- } \\
\text { Rata } \\
\text { Tes } \\
\text { Awal }\end{array}$ & $\begin{array}{c}\text { Nilai } \\
\text { Rata- } \\
\text { Rata } \\
\text { Tes } \\
\text { Akhir }\end{array}$ & $\begin{array}{c}\text { Peningka } \\
\text { tan } \\
\text { Nilai } \\
\text { Rata- } \\
\text { Rata } \\
\text { Kelas }\end{array}$ \\
\hline 1. & $\begin{array}{l}\text { Unsur } \\
\text { Pajak }\end{array}$ & 69 & 69 & 0 & 100 & 100 & 0 \\
\hline 2. & $\begin{array}{l}\text { Azas } \\
\text { pemun } \\
\text { gutan } \\
\text { pajak }\end{array}$ & 15 & 69 & 54 & 21,74 & 100 & 78,26 \\
\hline 3. & $\begin{array}{l}\text { Wajib } \\
\text { pajak }\end{array}$ & 10 & 69 & 59 & 14,49 & 100 & 85,51 \\
\hline 4. & $\begin{array}{l}\text { Hak } \\
\text { Wajib } \\
\text { pajak }\end{array}$ & 0 & 67 & 67 & 0 & 97,10 & 97,10 \\
\hline 5. & $\begin{array}{l}\text { Kewaji } \\
\text { ban } \\
\text { Wajib } \\
\text { pajak }\end{array}$ & 0 & 65 & 65 & 0 & 94,20 & 94,20 \\
\hline
\end{tabular}


Hasil analisis tersebut di atas dapat diilustrasikan dengan grafik di bawah ini:

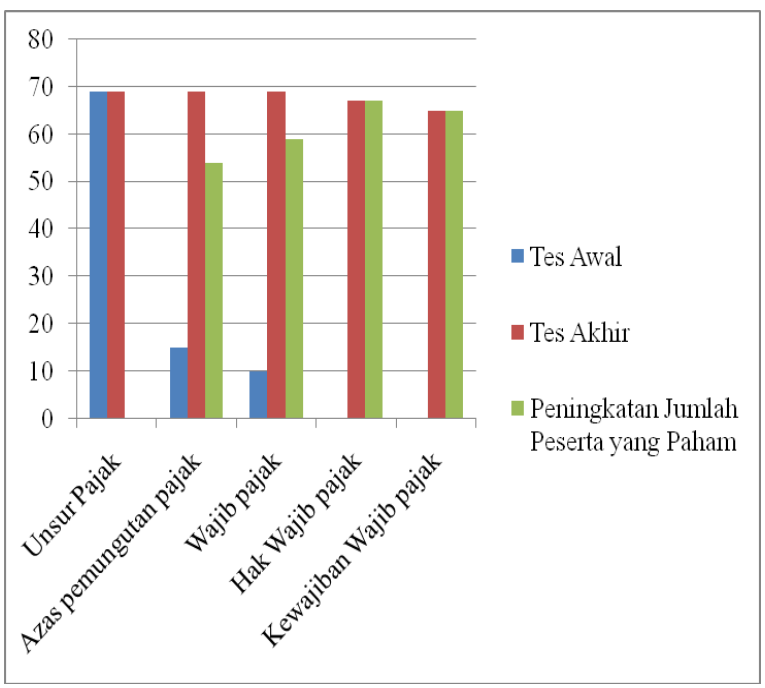

Gambar 4. Peningkatan Pemahaman Peserta Didik Kelas XII Jurusan IPA Sebelum dan Sesudah Penyuluhan Hukum

Setelah dilakukan penyuluhan hukum kepada para peserta didik kelas XII baik jurusan IPS dan IPA, terjadi peningkatan pengetahuan dan pemahaman terhadap hak dan kewajiban wajib pajak di atas $70 \%$. Dengan demikian, penyuluhan hukum ini memberikan manfaat semakin meningkatnya pengetahuan tentang hak dan kewajiban wajib pajak khususnya bagi kelas XII jurusan IPS di SMAN 10 Jakarta Pusat. Selama ini pengetahuan tentang pajak sudah cukup baik, namun perlu ditingkatkan agar wawasan hukumnya makin berkembang. Suatu hari nanti, mereka akan menjadi bagian dari masyarakat yang menjalankan aktivitas ekonominya atau lebih tepatnya mereka sebagai calon wajib pajak yang akan melaksanakan kewajiban perpajakan di saat mereka telah bekerja.

\section{KESIMPULAN DAN SARAN}

Berdasarkan uraian tersebut di atas, dapat disimpulkan bahwa penyuluhan hukum yang dilaksanakan dengan ceramah dan diskusi merupakan cara yang efektif untuk meningkatkan pengetahuan dan pemahaman para peserta didik khususnya kelas XII jurusan IPS di SMAN 10 Jakarta Pusat. Berdasarkan evaluasi yang dilakukan kepada seluruh peserta didik kelas XII jurusan IPA dan IPS, jumlah peserta didik yang mampu menjawab dengan benar rata-rata mengalami peningkatan di atas $70 \%$ setelah materi disampaikan. Dengan demikian, hampir seluruh peserta didik kelas XII khususnya jurusan IPS sudah memahami hak dan kewajiban wajib pajak.

Berdasarkan hasil yang dicapai, sebaiknya penyuluhan hukum hak dan kewajiban wajib pajak juga diberikan bagi peserta didik kelas X dan XI supaya mereka lebih memahami tentang hukum pajak sejak dini. Selain itu, dengan adanya penyuluhan ini akan mendorong peneliti akademis lain untuk mengkaji lebih lanjut mengenai urgensi pemahaman perpajkan sejak usia dini bagi optimalisasi kepatuhn dan penerimaan pajak.

\section{DAFTAR PUSTAKA}

Ahmadi, Wiratni. 2006. Perlindungan Hukum Bagi Wajib Pajak Dalam Penyelesaian Sengketa Pajak, Bandung: PT Refika Aditama

Brotodihardjo, R Santoso. 1993. Pengantar Ilmu Hukum Pajak, Bandung: Eresco

Direktorat Jenderal Pajak. 2016 Booklet Inklusi Kesadaran Pajak Dalam Pendidikan.

Rosdiana, Haula, Edi Slamet Irianto. 2012. Pengantar Ilmu Pajak Kebijakan dan Implementasinya di Indonesia, Jakarta: PT Rajagrafindo Persada

Saidi, M. Djafar. 2011. Pembaruan Hukum Pajak, Jakarta: PT Rajagrafindo Persada

Soekanto, Soerjono. 1986. Beberapa Cara Dan Mekanisme Dalam Penyuluhan Hukum, Jakarta: PT Pradnya Paramita

Soemitro, Rochmat. 1992. Pengantar Singkat Hukum Pajak, Bandung: PT Eresco

Winarno. 2011. Pendidikan Kewarganegaraan, Jakarta: Bumi, Aksara 